\title{
Teacher's Perception of The Contributions of Oil Exploration To Educational Development In Oguta L.G.A.
}

\author{
C. C. Ekwe \\ Alvan Ikoku Federal College Of Education, Owerri, Imo State \\ L.C. Ngozi-Olehi \\ Alvan Ikoku Federal College Of Education, Owerri, Imo State
}

\begin{abstract}
This study examined: Teachers Perception of the contributions of Oil Exploration on the Development of Education in Oguta Local Government Area of Imo State. Two research questions were developed and one null hypothesis was formulated. The design of the study was the population survey design. All the 80 teachers in Imo State Government owned schools were involved in the research. A 20 item researcher developed structured questionnaire was the instrument for data collection. Content validity was established for the questionnaire while the Cronbach alpha was used to establish its reliability. Data for answering the research questions were analyzed using mean score. The analysis of data for the null hypothesis was carried out with the t-test for independent samples and tested at 0.05 level of significance. The two research questions were answered in the negative. The null hypothesis was accepted and the findings showed that there is no relationship between the contributions of oil exploration and educational development in Oguta Local Government Area. The observational findings showed that the schools located in Oguta Local Government Area where in a state of abandonment. Among others researcher recommended that the Multinational Oil Companies bear the responsibilities of employing teachers who will teach in partner with teachers recruited by government in public schools located in Oguta Local Government Area. The educational implications of the findings were discussed. Suggestions for further studies were also put forward.
\end{abstract}

\section{INTRODUCTION}

Oil exploration in Nigeria can be traced back to 1907 when German surveyors working for the Nigerian Bitumen Corporation, carried out exploratory work for Tar Sand deposit in the SouthWestern Nigeria, although they left the country at the onset of the World War 1 . Subsequently licenses were given to D'Arcy Exploration Company and Whitehall Petroleum. Nigeria's proven oil reserves are estimated by the United States Energy Information (1997) at between 16 and 22 billion barrels $\left(2.5 \times 10^{9}\right.$ and $\left.3.5 \times 10^{9} \mathrm{~m}^{9}\right)$. Nigeria's reserves make her the tenth most petroleum-rich nation and by far the most affluent in Africa.

The most productive region of the nation is the coastal Niger Delta Basin in the Niger Delta or South-south region which encompasses 78 of the 159 oil fields. Most of Nigeria's oil fields are small and scattered, and as of 1990 , these small unproductive fields accounted for $62.1 \%$ of all Nigerian production. This contrasts with the sixteen largest fields which produced $37.9 \%$ of Nigeria's petroleum at that time (Khan, 1994). Offshore rigs are also located in the well endowed coastal region. According to a Niger Delta Environmental Survey carried out in September 1997 Nigeria owns a total of 159 oil fields and 1481 wells in operation. Her petroleum is classified mostly as light and sweet as the oil is largely free from sulphur. The oil is similar in composition to petroleum extracted from the North Sea. 
Educational development can be defined as helping colleges and universities function effectively as teaching and learning communities" (Felten, Kalish, Pingree, \& Plank, 2007). It could be referred to as actions "aimed at enhancing teaching" (Amundsen \& Wilson, 2012,). Sorcinelli, Austin, Eddy \& Beach (2005) defined Educational development as a "key lever for ensuring institutional quality and supporting institutional change.

\section{Statement of the Problem}

Educational development is regarded as a key tool for ensuring institutional quality and supporting academic and social change (Sorcinelli et al., 2005). It is expected that organizations like multinational companies operated in an area have some social responsibilities to fulfill. Part of this social responsibility is for such organizations to contribute positively to the educational development of the areas of operation like in the oil producing areas. The Federal Government of Nigeria obviously has policies that govern or oversee the implementation of Social responsibilities that affect educational development in oil producing areas.

As a result of the above this study will examine teachers perception of the impact of oil exploration on the educational development in Oguta Local Government Area of Imo State.

\section{Purpose of the Study}

The main purpose of this study was to investigate

1. Teacher's perception of the impact of oil exploration on the development of education.

2. The level of assistance of oil and gas companies to the educational needs of host communities.

3. The input of multinational oil companies in developing education in Oguta L.G.A.

4. How oil companies can help educators keep abreast of technological advancements that support innovations and improvements in instructional design and delivery.

\section{Significance of the Study}

Results from this investigation will help government and decision makers urge oil companies to support teacher training programs similar to that which is obtainable in their employees children's schools.

It is expected that the results from this study will improve information to the government on teacher training activities supported by multinational companies in the area.

Findings will help government articulate the rate of educational development influenced by oil exploration.

Both the study and its literature will help researchers working on related studies compile a sound literature on the matter and will also help teachers realize the need for current innovative trainings that facilitate learning.

Findings from the study will highlight critical aspects of educational development which has not been given proper attention in oil producing areas.

The study will help decision makers in education realize the need of incorporating oil exploratory companies in ensuring efficient teaching and learning by organizing useful teacher training programs and equipping laboratories annually to aid practical learning and science. 
Finally the study will direct oil exploratory companies and firms on the importance of contributing more to educational development as it directly affects learners attitude to learning in oil producing areas.

\section{Research Questions}

The following research questions where formulated to guide the study.

1. What is the perception of teachers on the contributions of oil exploration to educational development in Oguta Local Government Area?

2. What benefits do teachers perceive in the contributions of oil firms to teacher education in Oguta Local Government Area?

\section{Hypothesis}

The following hypothesis was raised:

There is no significant difference between male and female teachers perception of the contributions of oil exploratory companies to the educational development in Oguta Local Government Area.

\section{Research Methodology}

It describes the design of study, area of study, population of study, sample and sampling technique, instrument for data collection, validation and reliability of instrument, administration and scoring of instrument and method of data analysis.

The research design is a population survey design because the entire population of 80 (Eighty) teachers, teaching in the 10 (Ten) Government owned schools in Oguta Local Government Area was used for the study. There was no sample size and sampling technique used.

Table 1: Participants in the study

\begin{tabular}{|l|l|l|l|l|}
\hline S/N & \multicolumn{1}{|c|}{ NAME OF SCHOOL } & $\begin{array}{c}\text { NO OF } \\
\text { TEACHERS }\end{array}$ & \multicolumn{1}{|c|}{$\begin{array}{c}\text { NO OF } \\
\text { STUDENTS }\end{array}$} & $\begin{array}{c}\text { YOUTH MUST } \\
\text { WORK }\end{array}$ \\
\hline & OGUTA L.G.A & & & \\
\hline 1. & Agwa Sec. School & 9 & 1455 & 10 \\
\hline 2. & Comm Sec. Sch. Awa & 9 & 339 & 7 \\
\hline 3. & Egbuoma Sec. School & 10 & 825 & 6 \\
\hline 4. & Ejemekwuru/Akabor Sec. & 9 & 776 & 11 \\
\hline 5. & Eziorsu Sec. School & 4 & 394 & 7 \\
\hline 6. & Izombe Sec. Somm. Sch. & 10 & 735 & 11 \\
\hline 7. & Priscillia Mem Sec. Sch. & 9 & 1075 & 7 \\
\hline 8. & St. Michaels Sec. Sch Orsuobodo & 7 & 375 & 8 \\
\hline 9. & Trinity High School & 5 & 442 & 7 \\
\hline 10. & Umunwama Girls Sec Sch & 8 & 336 & 8 \\
\hline & TOTAL & $\mathbf{8 0}$ & $\mathbf{6 7 5 2}$ & $\mathbf{8 2}$ \\
\hline
\end{tabular}

A researcher developed structured questionnaire was used to gather data for answering the research questions and analyzing data for testing the hypothesis. It will be made up of 20 items. The response pattern to the questionnaire items is based on a modified 4 point Lickert scale with rating as follows. Strongly Agree $(S A)=4$, Agree $(A)=3$, Disagree $(D A)=2$, Strongly Disagree $(\mathrm{SD})=1$.

Face and content validity was established for the questionnaire items Test-retest reliability was obtained by administering the same questionnaire twice over a period of time to a group 
of teachers. The scores from Time 1 and Time 2 was then be correlated using a Cronbach's alpha in order to evaluate the test for stability over time.

\section{Data Collection Procedure}

The researcher went to the schools involved in the study and administered the questionnaires to the respondents. The researcher made explanations of items they found unclear. The questionnaires was collected on completion. This ensured the high return of the completed questionnaires.

\section{Data Analysis Procedure}

Mean score was used to analyze data for answering the research questions. The t-test was used to analyze data collected for testing the null hypotheses which was tested at 0.05 level of significance. The criterion mean is 2.5 calculated thus:

$$
x=\frac{4+3+2+1}{4}=10=2.5
$$

\section{RESULTS AND DISCUSSION OF FINDINGS}

This chapter dealt with data presentation and analysis. Data for each research question and hypothesis are presented in tables.

\section{Research Question One}

What is the perception of teachers of the contributions of oil exploration to educational development in Oguta Local Government Area?

\begin{tabular}{|c|c|c|c|c|c|c|c|c|c|}
\hline \multirow[t]{2}{*}{$\begin{array}{l}\text { Questionnaire } \\
\text { Items }\end{array}$} & \multirow[t]{2}{*}{$\begin{array}{l}\text { No of } \\
\text { Respondents } \\
\end{array}$} & \multicolumn{2}{|c|}{$\begin{array}{l}\text { Strongly } \\
\text { Agree }\end{array}$} & \multicolumn{2}{|c|}{ Agree } & \multicolumn{2}{|c|}{ Disagree } & \multicolumn{2}{|c|}{$\begin{array}{l}\text { Strongly } \\
\text { Disagree }\end{array}$} \\
\hline & & No & Score & No & Score & No & Score & No & Score \\
\hline $\begin{array}{l}\text { 1. Construction of } \\
\text { science laboratories }\end{array}$ & 63 & 7 & 28 & 10 & 30 & 11 & 22 & 35 & 35 \\
\hline 2. ICT facilities & 63 & 3 & 12 & 5 & 15 & 29 & 58 & 26 & 26 \\
\hline $\begin{array}{l}\text { 3. Employing } \\
\text { qualified teachers }\end{array}$ & 63 & 2 & 8 & 1 & 3 & 16 & 32 & 44 & 44 \\
\hline $\begin{array}{l}\text { 4. Reconstruction of } \\
\text { schools }\end{array}$ & 63 & 1 & 4 & 2 & 6 & 22 & 44 & 38 & 38 \\
\hline $\begin{array}{l}\text { 5. Availability of } \\
\text { transportation }\end{array}$ & 63 & 4 & 16 & 2 & 6 & 27 & 54 & 30 & 30 \\
\hline TOTAL & 315 & 17 & 68 & 20 & 60 & 105 & 210 & 173 & 173 \\
\hline
\end{tabular}

Table 2: Perception of teachers on the contributions of oil exploration to educational development in Oguta local government area.

Table 2 presents the questionnaire items and data for answering research question one. Data in table 4 show that the mean score of the responses is 1.62 which is lower than 2.5 , the mean score of decision making.

Findings in table 2 showed that teachers perception of the contributions of oil exploration firms to educational development in Oguta L.G.A. was negative. This finding of the present research is in line with that of Omotor (2000) which found that the oil industry impacted nonoil producing areas in Nigeria than the oil producing areas. 


\section{Research Question Two}

What benefits do teachers perceive in the contributions of oil firms to teacher education in Oguta Local Government Area?

\begin{tabular}{|c|c|c|c|c|c|c|c|c|c|}
\hline \multirow[t]{2}{*}{ Questionnaire Items } & \multirow[t]{2}{*}{$\begin{array}{l}\text { No of } \\
\text { Respondents }\end{array}$} & \multicolumn{2}{|c|}{$\begin{array}{l}\text { Strongly } \\
\text { Agree }\end{array}$} & \multicolumn{2}{|c|}{ Agree } & \multicolumn{2}{|c|}{ Disagree } & \multicolumn{2}{|c|}{$\begin{array}{l}\text { Strongly } \\
\text { Disagree }\end{array}$} \\
\hline & & No & Score & No & Score & No & Score & No & Score \\
\hline $\begin{array}{l}\text { 1. Lack of teacher } \\
\text { training support by } \\
\text { MNOCs }\end{array}$ & 63 & 39 & 156 & 7 & 21 & 7 & 14 & 10 & 10 \\
\hline $\begin{array}{l}\text { 2. Seminars and } \\
\text { Conferences }\end{array}$ & 63 & 3 & 12 & 1 & 3 & 29 & 58 & 30 & 30 \\
\hline 3. ICT training & 63 & 5 & 20 & 2 & 4 & 31 & 62 & 25 & 25 \\
\hline $\begin{array}{l}\text { 4. Teacher sensitization } \\
\text { programs }\end{array}$ & 63 & 4 & 16 & 6 & 18 & 13 & 26 & 40 & 40 \\
\hline $\begin{array}{l}\text { 5. Distribution of } \\
\text { laptops by oil } \\
\text { companies }\end{array}$ & 63 & 1 & 4 & 5 & 15 & 24 & 48 & 33 & 33 \\
\hline TOTAL & 315 & 52 & 208 & 21 & 61 & 104 & 208 & 138 & 138 \\
\hline
\end{tabular}

Table 3: Contributions of oil firms to teacher education in Oguta local government area

Table 3 presents the questionnaire items and data for answering research question three. Data presented on table 3 shows that the mean score of the responses is 1.95. Findings in table 3 of showed that teachers do not perceive any benefits in the contributions of oil firms to teacher education in Oguta Local Government Area. Findings of the present study are similar to that of Orji (2013) which showed that the crisis which has engulfed the Nigerian education sector especially in oil producing areas centers on lack of good teacher education policies and politicization of education, changing political environment, incessant change of educational policies and corruption.

\section{Hypothesis}

Hypothesis one was stated thus: There is no significant difference between male and female teachers perception of the contributions of oil exploratory companies to the educational development in Oguta Local Government Area.

Table 4: t-test for male and female teachers perception of oil firms contributions

\begin{tabular}{clllll}
\hline & Male & Female & Cal t & Table t & P level \\
\hline$\overline{\boldsymbol{x}}$ & 6.15 & 6.81 & -2.06 & 1.98 & 0.05 \\
SD & 1.31 & 1.73 & & &
\end{tabular}

$\mathbf{d f}=\mathrm{N}_{1}+\mathrm{N}_{2}-2=20+43+63-2=61$.

The findings in table 4 show that male and female teachers do not significantly differ in their perception of oil firms contribution to teacher education in Oguta Local Government Area.

The educational implication of this is that the quality of students being produced from these schools will remain poor or average.

This suggests that these oil companies lacked the morale to improve teacher education in host communities which could produce more effective and efficient teachers in these violent prone communities. 


\section{RECOMMENDATIONS OF THE STUDY}

As a result of the findings made in this study, the following recommendations are made for the development of education in Oguta Local Government Area.

1. The Niger Delta Development Commission and Multinational Oil Companies should sign an MOU that requires these companies to render developmental services to schools in host communities annually. They should be able to improve what is in place by renovating science laboratories and provide opportunity for teachers development intellectually. MNOCs need to provide sustainable and qualitative education that ultimately reaches all the people in these communities by employing teachers who will teach under their supervision and payroll to help teachers who are employed by the state governments measure up with the challenges of teaching in these communities.

2. More qualified teachers should be posted to these communities and attention should be directed towards issues involving the control of teachers, as in the case of teacher competency testing, certification, replacement of retired teachers and efficient supervision of in-service teachers. Teachers salaries in oil producing communities must be reviewed and improved. Fair wages will also motivate teachers to do their job on a high-quality level. Also, there should be regular payments of teachers' salaries. This will attract qualified and dedicated teachers to schools in these communities and will change the attitude of young people towards the teaching profession and youth will study to become teachers.

\section{CONCLUSIONS}

From the finding of data analysis the following conclusions were drawn.

* Teachers did not perceive oil exploration firms as contributing to the educational development of Oguta L.G.A.

* Teachers do not receive any benefits from the contributions of oil exploration firms.

\section{References}

Amunden, C. and Wilson, M. (2012). Are we asking the right questions? A conceptual review of the educational development literature in higher education. Review of Educational Research. 82: 90-126.

Felten, P., Kalish, A., Pingree, A. and Plank, K. (2007). Toward a scholarship of teaching and learning in educational development. In D. Robertson \& L. Nilson (Eds.), To Improve the Academy: Resources for Faculty, Instructional and Organizational Development. 25 : 93-108.

Khan, A. (1994). Nigeria: The Political Economy of Oil ISBN 0-19-730014-6

Omotor, D. G. (2008).The impact of oil exploration on the inhabitants of the oil producing areas of Nigeria. Journal of Food, Agriculture and Environment (JFAE).2: 726-730.

Orji, K.E.(2013). The Role of Education in National Development: Nigerian Experience. European Scientific Journal. 28: $1857-1868$.

Sorcinelli, M.D., Austin, A.E., Eddy, P.L. and Beach, A.L. (2005). Creating the future of faculty development: Learning from the past, understanding the present. San Francisco: Jossey-Bass.

United State Energy Information Administration (U.S. EIA), “Nigeria Country Analysis Brief,” December 1997. 